\title{
FEEDBACK ON FORMATIVE ASSESSMENTS IN UNDERGRADUATE MEDICAL EDUCATION OF BANGLADESH
}

\author{
KAZI KHAIRUL ALAM ${ }^{1}$, SHAMSUN NAHAR BEGUM ${ }^{2}$, TAHMINA NARGIS ${ }^{3}$, MD. FARUQUE ${ }^{4}$
}

${ }^{1}$ Lecturer, Centre for Medical Education (CME), Mohakhali, Dhaka, ${ }^{2}$ Professor and Head, Department Community Medicine, Enam Medical College, Savar, Dhaka, ${ }^{3}$ Research Associate, CME, Dhaka, ${ }^{4}$ Professor (CC), Dental Anatomy, Dhaka Dental College, Dhaka

\begin{abstract}
The study was conducted to examine the extent and methods of giving feedback by teachers after the formative assessments to the undergraduate medical students of Bangladesh.

This descriptive study was conducted in four purposively selected medical colleges of Dhaka. Views of 174 teachers and 332 students were collected through self-administered semi-structured questionnaires for this purpose.

It was found that majority of the teachers perceived that through feedback students find out their weaknesses and thereby can perform better in future. It was also found that feedback was not given in most of the cases by the teachers to their students. The methods of giving feedback were not perfect all together.
\end{abstract}

To ensure feedback after the formative assessments teachers should be motivated and trained up and it should be mentioned in the curriculum that feedback is mandatory.

Key words: Formative assessment, Feedback, Medical education of Bangladesh, Assessments in medical education, Undergraduate curriculum Bangladesh.

(Bangladesh J Physiol Pharmacol 2009; 25(1\&2) : 18-22)

\section{INTRODUCTION}

Simplest meaning of formative assessment is the assessment that is carried out frequently and is planned at the same time as teaching. ${ }^{1-2}$ This formative assessment is forward looking provides feedback which leads to students to recognise their learning gap and closing it. The most powerful single moderator that enhances students' achievement is feedback in formative assessment. ${ }^{1-9}$

Feedback is most effective if it focuses students' attention on their progress in mastering educational tasks. Feedback should take soon after a task is completed and that the student should be given opportunities subsequently to demonstrate learning from the feedback and the feedback should be specific and related to need. . $10-12^{1}$

Feedback to any pupil should be about the particular qualities of his or her work, with advice on what he or she can do to improve, and should avoid comparisons with other pupils. $2,8,10,13$

Correspondence: Kazi Khairul Alam, Centre for Medical Education (CME), Mohakhali, Dhaka. E-mail: khairul1214@yahoo.com
Feedback in a formative assessment context occurs while there is still time to take action. Although all formative assessment practices have the potential to increase student learning, formative assessment in the classroom also enables teachers to adjust instruction quickly, while learning is in progress. $7,14,15$

There are three-step in feedback of formative assessment is called the 'feedback loop'; that is, 1) setting a learning goal, 2) determining the gap between the learning goal and the student's present state of understanding, and 3.) Formulating feedback to close the gap. ${ }^{16}$ To inform the students about the gap, the teacher can include eliciting students' thinking through verbal or written prompts, reviewing students' notebooks or homework, or listening to small-group conversations, so that students can compare there level of performance with the goal. The gap can be close by describing new procedures, explaining how a sentence could be edited for more clarity, by re-teaching certain concept, allowing students to review the work of peers provides them the opportunity to see how the work of others might be improved. 17,18 
Feedback can be classified as either: 1.) Evaluative - involving a value judgment, or 2.) Descriptive describing what the student said or did. Examples of evaluative feedback: "That's a good essay", "You've done well". An example of descriptive feedback: "That's a good essay because you have covered the main points we discussed at the beginning. Now ... which points do you think you could expand on ${ }^{19}$ The feedback needs to be of two kinds: in addition to better feedback after the performance, feedback must also be provided during (concurrent with) the assessment activities. ${ }^{20}$ There are some controversies about whether formative assessment might be documented. Some ague that formative assessment can be use to improve teaching and learning regardless of curriculum context. On the on the other hand some strongly recommended that formative assessment must be embedded in curriculum to make it rich. ${ }^{21}$

Keeping in mind the undergraduate curriculum 2002 for MBBS (Bachelor of Medicine Bachelor of Surgery) students of Bangladesh has given high importance on formative assessments. Item exam, card final, and term final are the formative assessments in the MBBS course, which was designed to improve quality of learning and better performance of students in the summative assessments. Ten percent marks from the formative assessments are added with the summative examinations. ${ }^{22}$ In 2008 first batch of students graduated under this curriculum. Now we should start reviewing our existing curriculum for it's development. Feedback with the formative assessment is very important issue for students' learning. The present section of the study desired to evaluate how feedback is given after formative assessment in MBBS course in the medical colleges of Bangladesh.

\section{METHODOLOGY}

This study was cross-sectional type and was conducted from January 2008 to June 2008 in purposively selected two government medical colleges and two nongovernment medical colleges of Dhaka city. A total of 174 teachers and 332 students (120 phase-1, 110 phase-2 and 102 phase-3 students*) expressed their views by responding to slightly different four semi-structured selfadministered questionnaires.

[ ${ }^{*}$ Phase- 1 is first $1 \frac{1}{2}$ year, phase- 2 is middle 2 years and phase- 3 is last $1 \frac{1}{2}$ years of the MBBS curriculum 2002].

\section{RESULT}

Table-I shows that in only about $46 \%$ teachers always or in almost most all cases gave feedback to their students and $27 \%$ teachers gave it in majority of cases after the formative examinations of the students, rest of the teachers never or rarely or sometimes provided feedback to their students. On the other hand, table 2 shows that only about $17 \%$ teachers always or in almost most all cases gave back the written script to their students, about $8 \%$ teachers gave it in majority of cases after the formative examinations of the students, rest of the teachers never or rarely or sometimes gave back the written script.

Table-I

Distribution of teachers by their opinion regarding the extent of feedback given to the students after their formative assessment $n=173$

\begin{tabular}{lc}
\hline Extent of practice & $\%$ \\
\hline Never (in 0\% cases) & 1.7 \\
Rarely (in <25\% cases) & 5.2 \\
Sometimes (in 25-<50\% cases) & 19.6 \\
In majority of cases (in 50-<75\% cases) & 27.7 \\
Al most all cases (in 75-95\% cases) & 20.2 \\
Always (in 100\% cases) & 25.4 \\
\hline
\end{tabular}

Table-II

Distribution of teachers by their opinion regarding the extent to which written answer script is given back to students after their formative assessment $n=170$

\begin{tabular}{lc}
\hline Extent of practice & $\%$ \\
Never (in 0\% cases) & 17.5 \\
Rarely (in <25\% cas) & 26.3 \\
Sometimes (in 25-<50\% cases) & 31.7 \\
In majority of cases (in 50-<75\% cases) & 7.6 \\
Al most all cases (in 75-95\% cases) & 8.1 \\
Always (in 100\% cases) & 8.7 \\
\hline
\end{tabular}

Table 3 and table 4 show that the most important reason (89\%) for giving feedback or giving back the written answers scripts were to help the students to find out their weakness and to perform better in future. Besides, teachers' interest and interest of the authorities played important role for this type of practices. The teachers felt that giving back the written scripts to the students also increased the academic transparency and teachers' sincerity in rating the answer scripts. 
Table-III

Distribution of teachers by their opinion regarding the reasons for giving feedback to the students after their formative assessment $n=170$

\begin{tabular}{lc}
\hline Reasons & $\%$ \\
Students understood their weakness and & 89.10 \\
find out how to perform better in the & \\
examinations & \\
Was given by self interest & 32.90 \\
There was order of higher authority & 7.10 \\
Other causes & 0.60 \\
\hline
\end{tabular}

[Exceed $100 \%$ due to multiple responses. This table excludes opinion of those teachers who never gave feedback to the students]

Table-IV

Distribution of teachers by their opinion regarding the reasons for giving back the written answer scripts to the students after their formative assessment

$$
n=138
$$

\begin{tabular}{lc}
\hline Reasons & $\%$ \\
Students understood their weakness and & 89.10 \\
find out how to perform better in written test & \\
Ensured transparency of the examinations & 36.20 \\
Was given by self interest & 26.10 \\
Teacher remained alert during checking & 23.90 \\
the scripts & \\
There was order of higher authority & 5.80 \\
Other causes & 0.60 \\
\hline
\end{tabular}

[Exceed 100\% due to multiple responses. This table excludes opinion of those teachers who never gave back written answer to the students]

Table $\mathrm{V}$ and table 6 show that the common cause for not giving feedback (43\%) or not giving back the written answer scripts (40\%) to the students by the teachers was as it was not written in the curriculum. Some teachers have expressed that giving feedback was wastage of class time; they did not practice as there was no order of higher authority, and they had to work hard. Table 6 also indicate that the important causes for not giving back the written answer scripts to the students by the teachers are as students tried to increase number instead of understanding their error, there was less importance of written test than viva and practical assessments, students tried to find out teachers fault.
Table-V

Distribution of teachers by their opinion regarding the reasons for not giving feedback to the students after their formative assessment $n=67$

\begin{tabular}{lc}
\hline Reasons & $\%$ \\
\hline Not written in curriculum & 43.30 \\
Wastage of class time & 38.80 \\
No order of higher authority & 25.40 \\
Teachers have to work hard & 19.40 \\
Other cause & 13.40 \\
\hline
\end{tabular}

[Exceed 100\% due to multiple responses. This table excludes opinion of those teachers who always gave feedback to the students]

Table-VI

Distribution of teachers by their opinion regarding the reasons for not giving back the written answer script to the students after formative assessment $n=88$

\begin{tabular}{lc}
\hline Reasons & $\%$ \\
\hline Students tried to increase number & \\
instead of understanding their error & 61.40 \\
Was not written in curriculum & 39.80 \\
Less importance of written test. than viva & \\
and practical assessments & 11.40 \\
Students tried to find out teachers fault & 6.80 \\
Other causes & 13.60 \\
\hline
\end{tabular}

[Exceed 100\% due to multiple responses. This table excludes opinion of those teachers who always gave back written answer scripts to the students]

Table-VII also shows that, the very few (12\%) students mentioned that they always or in almost all cases received feedback from the teachers after their formative viva. Similarly only $16 \%$ students always or in almost all cases received feedback after formative practical assessments. But about 73\% students mentioned that they never received feedback after their formative written tests. This table also indicates that students had received feedback from the teachers to variable extent although these were not extensive. 
Table-VII

Distribution of students by their opinion regarding the extent of feedback they got after their formative assessment

\begin{tabular}{lccc}
\hline $\begin{array}{l}\text { Extent of } \\
\text { feedback } \\
\text { received }\end{array}$ & $\begin{array}{c}\text { After } \\
\text { written } \\
\text { test } \mathrm{n}=328 \\
\%\end{array}$ & $\begin{array}{c}\text { After } \\
\text { viva } \\
\mathrm{n}=329 \\
\%\end{array}$ & $\begin{array}{c}\text { After Practical } \\
\text { assessment } \\
\mathrm{n}=325 \\
\%\end{array}$ \\
\hline Never & 72.8 & 18.2 & 17.0 \\
Rarely & 16.2 & 33.7 & 29.5 \\
Sometimes & 7.9 & 25.0 & 22.8 \\
In majority of cases & 3.0 & 11.9 & 14.8 \\
Al most all cases & 0.0 & 7.0 & 9.8 \\
Always & 0.0 & 4.9 & 6.2 \\
\hline
\end{tabular}

Table-VIII has shown distribution of students by their opinions regarding how they received feedback after formative assessments. It was found that the students received feedback during lecture (77\%) and during tutorial/ practical class (62\%). The feedback was given by own batch teachers (50\%) and only to those students who communicated with the teachers (42\%). They also mentioned that feedback was given only to those students who performed badly or who could perform better in future. This was also given outside the class hour but never individually to every student.

Table-VIII

Distribution of students by their opinions regarding how they received feedback after formative assessments $n=320$

\begin{tabular}{lc}
\hline How feedback students received & $\%$ \\
\hline During lecture & 76.5 \\
During tutorial/ practical class & 61.8 \\
Given by own batch teachers & 49.6
\end{tabular}

Only to those students who communicate

with the teachers

Given by group of teachers together

Only to those students who have performed bad

Outside the class hour

Given to every students individually

Only to those students who can performed better

in future

Other means of feedback

[Exceed $100 \%$ due to multiple responses]

\section{DISCUSSION}

From the teachers' opinions it was found that giving feedback and giving back the written answer scripts to the students after their examination was not a usual practice in the medical institutes. Similarly students' views also indicated that getting feedback from teachers after the written, viva and practical formative assessments were very unusual in the medical colleges. It was already mentioned that many research reports have quoted that feedback is most important and central issue in formative assessment; in other word without feedback formative assessment is useless. 1-21

Even had the high rate of negatives practice of giving feedback or giving back the written answer scripts to the students by the teachers most of them (89\%) agreed that through these feedback students could find out their weakness and could identify the way to improve in future. This finding had consistency with the other research finding that feedback in formative assessment helps the students to identify the learning gap and close it. ${ }^{1,4-}$ $7,7,8,12,16$ This finding also indicated teachers of the medical colleges were able to perceive the importance of feedback.

From teachers' view it was identified that the common reason for not giving feedback and giving back the written scripts to the students was feedback was not mentioned as mandatory in curriculum. This findings had consistency with Assaduzaman's ${ }^{23}$ study, which had found that in $81 \%$ of respondents (teachers and students) mentioned that written script was not given back to the students after their formative assessments. These findings also indicated that we should make mandatory in the curriculum that feedback and written scripts must be given to the students after their formative assessments. The major reason (61\%) for not giving the written scripts to the students was as the students did not search their own weakness rather they tried to increase their marks. This explanation indicated that teachers were not scoring the written scripts objectively using structured rating scales or they did not sincerely checking the written scripts of the examinations, so they were afraid that students might find out their faults and reasonably might claim to increase their marks.

Whatever the minimum rate of practice of feedback in the medical colleges, the students also mentioned that they got feedback from their teachers mostly (77\%) in common classes like in lectures or tutorials. But we know feedback should be specific to the learner need targeting to close his / her learning gape.7,8,2 The feedback is useless if it is given in a common class unless it is a common weakness of all students ${ }^{17}$. Asaduzaman ${ }^{23}$ have found in his study on formative study that only $30 \%$ students of phase- 2 have mentioned that 
the reason of their failure in their test was well explained to them by the teachers and only $7 \%$ students agreed that the teachers discussed with them regarding their individual difficulties, though $76 \%$ of students mentioned that they got the suggestion regarding their failure in general from the teachers. In his study he found that majority of phase-2 students got feedback from teachers which guide them to do better learning through selecting appropriate approach and finding the way of improvement. Another important finding was presented by Aasaduzaman ${ }^{23}$ was that feedback was commonly given to the students of phase-2 in their item examinations, whereas it was rare in card and term examinations.

\section{CONCLUSION AND RECOMMENDATION}

Feedback on formative assessments was not practiced properly in our medical colleges quantitatively or qualitatively, though most of the medical teachers were aware of it importance. We should arrange workshops and seminars for the teachers of the medical colleges to motivate and to ensure proper practice of feedback after the formative assessments. We can also make feedback as mandatory in the curriculum.

\section{ACKNOWLEDGEMENT}

We are grateful to Director Medical Education of Director General of Health Service, Dhaka Bangladesh for partial financial support.

\section{REFERENCES}

1. Rahman SA. Promoting learning outcome in paediatrics through formative assessment. Medical Teacher 2001;23(5):467-70.

2. Burch VC, Seggie JL, Gary NE. Formative assessment promotes learning in undergraduate clinical clerkships. South African Medical Journal 2008; 96: 430-3.

3. Ronald M, Epstein MD. Assessment in Medical Education, The new England Journal of Medicine 2007;356(4): 387-96.

4. Rushton A. Formative assessment: a key to deep learning? Medical Teacher 2005;27(6):509-13.

5. Olson $\mathrm{BI}, \mathrm{Mcdonald} \mathrm{JI}$. Influence of online formative assessment upon student learning in biomedical science courses. Journal of Dental Education 2004; 68(6):656-9.

6. Mitchell J, Mitchell G. Student assessment in anatomy: is a final examination necessary? Medical Teacher 1998;20(3):261-3.

7. Vag M, Avadhhany ST, Rao BS. Student perspective on the role of formative assessment in physiology. Medical Teacher 1996;18(4):324 - 6 .

8. Chappuis S, Chappuis J. The Best Value in Formative Assessment. Educational Leadership 2008;65(4);14-9.
9. Cheng $\mathrm{MH}$, So WM, Cheung WM. Current trend in Science education. Asia-Pacific Forum on Science Learning and Teaching 2000; I(2):article no.2.

10. Chairman D, Elmes A. A computer-based formative assessment strategy for a basic statistics module in geography. Journal of Geography in Higher education 1998;22(3):381-5.

11. Black P, William D. Inside the black box: raising standards through classroom assessment, (no date), viewed 12 February2008, <http://www.pdkintl.org/kappan/ kbla9810.htm>

12. Wigton RW, Patil KD, Hoellerich VL. The effect of feedback in learning clinical diagnosis. Journal of Medical Education 1986; 61:816-22.

13. Norcini J, Burch V. Workplace- based assessment as an educational tool: AMME Guide No. 31. Medical Teacher 2007;29:855-71.

14. Voloski J, Boex JR, Grasberger MJ, Erans A, Wlfson DB. Systematic review of the literature on assessment, feedback and physicians' clinical performance: BEME guide No. 7. Medical Teacher 2006;25(2):117-28.

15. Khan KS, Davies DA, Gupta J K. Formative self assessment using multiple true false questions on the Internet: feedback according to confidence about correct knowledge. Medical Teacher 2001;23(2):158-63.

16. Liberman AS, Liberman $M$, Steinert $Y$, Macleod $P$, Meterissian $S$. Surgery residents and attending surgeons have different perceptions of feedback. Medical Teacher 2005;27(5):405-72.

17. Shumway JM, Harden RM. AMEE Guide No.25: The Assessment of outcomes for the competent sand reflective physician. Medical Teacher 2003;25(6):569-84.

18. Sinclair HK, Cleland J. Undergraduate medical students: who seeks formative feedback? Medical Education 2007;41:580-2.

19. Houghton G, Wall D. Trainers' evaluations of the west midlands formative assessment package for GP Register assessment. Medical Teacher 2000; 22(4):399-405.

20. Goldie J. AMEE Education Guide No. 29: Evaluating educational programmes. Medical Teacher 2006; 28(3):210-24.

21. Taradi SK, Taradi M, Radic K. Integration of online formative assessment into medical education: Experience from University of Zagreb Medical School, Croatia, The National Medical Journal of India 2005;18(1):39-40.

22. Centre for Medical Education. Curriculum for undergraduate medical education in Bangladesh 2002. Centre for Medical Education, Mohakhali, Dhaka-1212.

23. Asaduzaman AKM. Practice of formative assessment in $2^{\text {nd }}$ professional MBBS subjects: opinion of $4^{\text {th }}$ Year Medical Students. Centre for Medical Education 2008. Mohakhali, Dhaka. 